Volume 2 Issue 2, July-December 2021: pp.87-102.

Faculty of Law, Universitas Lampung, Bandar Lampung, Indonesia.

http://jurnal.fh.unila.ac.id/index.php/ip

P-ISSN: 2723-2638 E-ISSN: 2745-9314

\title{
Harmonization of Rehabilitation Service Standards for Drug Abuse's Addicts and Victims according to the Regulations
}

\section{Refi Hendra}

National Narcotics Agency Metro District, Indonesia

refi.hendra@gmail.com

Submitted: Jan 14, 2021; Reviewed: Jan 15, 2021; Accepted: Feb 1, 2021

Article's Information

keywords:

Harmonization; Legislation; Service Standards.

DOI :

https://doi.org/10.25041/ip.v2i2.2216

\section{Abstract}

Narcotics addicts and victims of narcotics abuse must undergo medical and social rehabilitation, according to Article 54 of Indonesia's Narcotics Law. The government then issued a rehabilitation policy for them under the authority of three state institutions, namely the Ministry of Health, the Ministry of Social Affairs, and the National Narcotics Agency. This causes overlapping and tug-of-war among stakeholders when it comes to developing policies and implementing rehabilitation services for addicts and victims of narcotics abuse, resulting in no method that becomes a guideline for rehabilitation implementation, on the report of an Ombudsman study. The aim here is to investigate how the laws of Rehabilitation Service Standards for Addicts and Victims of Drug Abuse are harmonized. The approach used is normative juridical. According to the study's findings, the regulations are hierarchically aligned, but the implementation of each rehabilitation program has a Service Standard. There is a vertical disparity in the definitions of medical and social rehabilitation and service providers and service recipients. Horizontally, there are differences in the determination of the implementing agency, service standards such as service programs, human resources, infrastructure, and activity funding sources. As a result, medical and social rehabilitation implementation is separated, resulting in a lack of comprehensive services for service recipients. 


\section{A. Introduction}

Narcotics are medicinal compounds derived from plants or synthetic materials. They can cause a decrease or change in consciousness, and relieving pain can eventually lead to dependence, grouped into several categories. ${ }^{1}$ Narcotics addiction is a condition arising from the desire to use narcotics non-stop, and if it is stopped suddenly, there will be signs of changes in the body and a deviant mind-set. ${ }^{2}$ People who have been exposed to Narcotics will get health problems. According to the understanding contained in Article 1 Paragraph (1) of Law Number 36 of 2009 concerning Health, health is a healthy state physically, mentally, spiritually, and socially, enabling everyone to live productively, socially, and economically.

A Narcotics Addict experiences mental health problems due to the substances' effects caused by the substances used. People who experience mental health problems have experienced physical, psychological, social, growth, development problems, and/or quality of life, so they are at risk of experiencing mental disorders. ${ }^{3}$ The Rehabilitation Program for addicts and narcotics abusers is a mental health effort. Rehabilitation is one method of rescuing victims of drug users from addiction so that they can live a normal life as well as readjust and improve their socialization to society. ${ }^{4}$ The abuse of Narcotics in Indonesia is a serious problem because the imposition of criminal penalties and even the death penalty for the perpetrators, which are expected to have a deterrent effect, have not succeeded in making Indonesia clean from narcotics crime. ${ }^{5}$

The ability of criminal law to deal with crimes has limitations. ${ }^{6}$ Criminal punishment and rehabilitation for victims of substance abuse in Indonesia are not yet unilateral in the treatment of drug offenses. The synergy between the National Narcotics Agency (Badan Narkotika Nasional Indonesia/ BNN) and Indonesian National Police is required in order to prevent and eradicate not only drug addiction but also drug trafficking. ${ }^{7}$ The government issued a policy to overcome this problem. The main causes of the increasing number of narcotics addicts in Indonesia are narcotics abuse and distribution. As a result, the Indonesian government has developed a narcotics policy that will allow for the treatment of both narcotics addicts and non-narcotics addicts. ${ }^{8}$ A rehabilitation program for addicts and victims of narcotics abuse was organized to reduce the high rate of narcotics abuse. The rehabilitation program for addicts and victims of narcotics abuse in Indonesia has been regulated in various regulations or laws: ${ }^{9}$

\footnotetext{
${ }^{1}$ Article 1 of Law of the Republic of Indonesia Number 35 of 2009 concerning Narcotics.

2 Muhammad Fajrul Falah, "Reformulasi Penetapan Sanksi Rehabilitasi Bagi Pecandu Narkotika," JURNAL LEGALITAS 12, no. 1 (February 3, 2019): 25-47, https://doi.org/10.33756/JELTA.V12I1.5380.

${ }^{3}$ Article 1 of Law of the Republic of Indonesia Number 18 of 2014 concerning Mental Health.

4 Susiyanto, Randy Pradityo, and Rosyidin, "Rehabilitation Of Narcotic Abuse Victims: (Integrated Assessments from National Narcotics Board of Indonesian Republic ) Turkish Journal of Computer and Mathematics Education," Turkish Journal of Computer and Mathematics Education 12, no. 13 (2021): 4150-53.

5 Muntaha, Hukum Pidana Malapraktik: Pertanggungjawaban Dan Penghapus Pidana (Jakarta Timur: Sinar Grafika, 2017).

${ }^{6}$ Eddy Rifai, Penegakan Hukum Tindak Pidana Korupsi (Bandar Lampung: Justice Publisher, 2014).

${ }^{7}$ Sri Warjiyati, Daniel Susilo, and Suyanto, "Justice Collaboration on Social Media: Drugs and Narcotics Abuse Prevention Promotion," Journal of Drug and Alcohol Research 9 (2020): 1-6, https://doi.org/10.4303/jdar/236111.

8 Yusuf Saefudin, Hartiwiningsih, and Isharyanto, "Rehabilitation Policy for Drugs Abuse in Indonesia," Indian Journal of Forensic Medicine \& Toxicology 14, no. 4 (2020): 4111-15.

9 Ari Iswahyuni, "Kedudukan Ancaman Pidana Minimal Dalam Undang- Undang Nomor 35 Tahun 2009 Tentang Narkotika Pasca Dikeluarkannya Surat Edaran Mahkamah Agung Nomor 3 Tahun 2015," Jurnal Panorama Hukum 3, no. 1 (July 5, 2018): 19-32, https://doi.org/10.21067/jph.v3i1.2321.
} 


\section{Law Number 35 of 2009 concerning Narcotics}

This law regulates narcotics, which is to prevent and eradicate Narcotics' abuse and illicit trafficking, which are very detrimental and endanger the life of the community, nation, and state. It also includes the death sentence for drug offenses, but not for victims of drug abuse or individuals who solely use drugs ${ }^{10}$.

2. Government Regulation of the Republic of Indonesia Number 25 of 2011 concerning The Mandatory Report for Narcotics Addicts.

In this regulation, another objective of the mandatory implementation of the mandatory report on Narcotics Addicts is to involve parents, family, and society in increasing responsibility for narcotics addicts who are under their supervision and guidance. Besides that, implementing mandatory reporting is also an information material for the government in determining policies in the field. Prevention and eradication of the abuse and trafficking of narcotics.

3. Regulation of the Ministry of Health Number 50 of 2015 concerning Technical Guidelines for the Implementation of Compulsory Medical Report and Rehabilitation for Addicts, Abusers, and Victims of Narcotics Abuse.

With the implementation of this Regulation of the Ministry of Health, it is hoped that it can become a reference for the central government, local governments, and all public health centre, hospitals, and Medical Rehabilitation Institutions for the implementation of the IPWL determination and the mandatory reporting and medical Rehabilitation for addicts, abusers, and victims of Narcotics abuse.

4. Regulation of the Ministry of Social Affairs Number 9 of 2017 concerning National Standards for the Social Rehabilitation of Victims of Narcotics Abuse, Tropical Psychology, and other Addictive Substances.

This ministerial regulation was established so that people are aware of it. The regulation also orders the promulgation of a Ministerial Regulation.

5. Regulation of the Head of the National Narcotics Agency of the Republic of Indonesia Number 24 of 2017 concerning Rehabilitation Service Standards for Narcotics Addicts and Victims of Narcotics Abuse.

This ministerial regulation is essential because it provides recovery and cares through Rehabilitation of abuse, narcotics addicts, and narcotics abuse in an effective and quality manner.

6. Local Regulation of Lampung Province Number 1 of 2019 concerning Facilitation for the Prevention of Abuse of Narcotics, Psychotropic, and other Addictive Substances.

Prevention and handling of narcotics, psychotropic, and other addictive substances can be carried out in a coordinated manner by the Regional Apparatus Organization, vertical agencies, and the community in Lampung Province, so it is necessary to stipulate regional regulations regarding the Abuse of Narcotics, psychotropic and other Addictive Substances.

Rehabilitation services for addicts and victims of narcotics abuse are the duty and authority of the Ministry of Health, Ministry of Social Affairs, and the National Narcotics Agency. This causes overlapping and a tug-of-war between the stakeholders in setting policies and implementing rehabilitation services for addicts and narcotics abuse victims. ${ }^{11}$ The Ombudsman study found that no method becomes a guideline for implementing Rehabilitation. Ministries/agencies make their respective regulations. In the second semester

\footnotetext{
${ }^{10}$ Sabarinah, "Use of Drug Treatment and Rehabilitation Services in Indonesia: Findings of the 2014 National Narcotic Survey," Asia-Pacific Journal of Public Health 31, no. 6 (2019): 548-58, https://doi.org/10.1177/1010539519872343.

11 Anggelina Hariyanti, "Strategi Program Pencegahan Penyalahgunaan Narkoba Pada Badan Narkotika Nasional Provinsi Kalimantan Tengah," Pencerah Publik 6, no. 2 (October 7, 2019): 9-15, https://doi.org/10.33084/pencerah.v6i2.1075.
} 
of 2017, the Ministry of Social Affairs set a national standard for narcotics rehabilitation through the Ministry of Social Affairs Regulation Number 9 of 2017, while the Ministry of Health through the Ministry of Health Regulation Number 50 of 2015 and the National Narcotics Agency of Indonesia or Badan Narkotika Nasional (BNN) through the Regulation of the Head of the National Narcotics Agency Number 24 of 2017. ${ }^{12}$ Until November 2015, the number of people exposed to narcotics in our country was 5.9 million people or $2.3 \%$ of Indonesia's total population. ${ }^{13}$ The number who get rehabilitation services is only 15,302 narcotics abusers or only $0.38 \%$ of the number of addicts who get narcotics rehabilitation services.

Rehabilitation is an integrated service process to free addicts and victims of narcotics abuse from their dependence, which includes health, mental, social, and spiritual health and vocational aspects so that they can return to carrying out social functions in society. Rehabilitation institutions that provide rehabilitation services for addicts and victims of narcotics abuse in children are rehabilitation centres and/or rehabilitation centres. The rehabilitation service program for addicts and victims of narcotics abuse in children refers to the implementation standards of medical Rehabilitation and social Rehabilitation and national standards of care for social welfare institutions. The separation of medical and social Rehabilitation makes Rehabilitation incomplete because Rehabilitation is not only a medical problem handling when an abuser shows withdrawal symptoms. ${ }^{14}$ Handling the social problems experienced by addicts is equally essential to prevent former users from returning to society.

President Joko Widodo issued Presidential Instruction No.6 of 2018 concerning the National Action Plan for the Prevention, Eradication of Narcotics Abuse and Illicit Narcotics or Rencana Aksi Nasional Pencegahan, Pemberantasn Penyalahgunaan dan Peredaran Gelap Narkotika (P4GN) on July $2018 .^{15}$ As the joint responsibility for several relevant ministries, the National Narcotics Agency is instructed to carry out capacity building for rehabilitation services for victims of narcotics abuse and narcotics precursor nationally. Developing a national standardization of rehabilitation services with indicators of success in compiling a national standard of sustainable rehabilitation services.

The legislation (law in the books) for the implementation of rehabilitation services already has a division of tasks, namely medical Rehabilitation is carried out by the Ministry of Health and Social Rehabilitation by the Ministry of Social Affairs, but implementation in the field of separation where Rehabilitation is experiencing various obstacles from service recipients and service providers, as regulated in Article 54 of Law Number 35 of 2009 concerning Narcotics. ${ }^{16}$ Facts on the reality (law in action) is set through the Ministry of Health that applies social Rehabilitation and vice versa. The Ministry of Social Affairs also carries out medical Rehabilitation because Rehabilitation is a long process that is not only partially given and must be undertaken by narcotics users to recover, be productive, and social function.

\footnotetext{
12 Muhammad Hatta, "Mati Suri Rehabilitasi Adiksi," Tempo, 2019, https://kolom.tempo.co/read/1175460/matisuri-rehabilitasi-adiksi/full\&view $=$ ok.

${ }^{13}$ Ira Rachmawati, "Buwas: Pengguna Narkoba Di Indonesia Meningkat Hingga 5,9 Juta Orang,” Kompas.com, 2016, https://regional.kompas.com/read/2016/01/11/14313191/Buwas.Pengguna.Narkoba.di.Indonesia.Menin.

14 Sri Handayani Irfan Ardani, "Stigma Terhadap Orang Dengan HIV/AIDS (ODHA) Sebagai Hambatan Pencarian Pengobatan: Studi Kasus Pada Pecandu Narkoba Suntik Di Jakarta ," Indonesian Bulletin of Health Research 45, no. 2 (2017): 81-88, https://doi.org/10.22435/bpk.v45i2.6042.81-88.

15 Attachment to Presidential Instruction Number 6 of 2018 concerning the National Action Plan for the Prevention and Eradication of the Abuse and Illicit Narcotics and Narcotics Precursor 2018-2018, pg 14.

16 Narcotics Addicts and Narcotics Abuse Victims are required to undergo Medical Rehabilitation and Social Rehabilitation.
} 
There is a need for a scientific study of statutory regulations on harmonizing legislation vertically and horizontally, which is very much needed for the certainty and balance of harmonious laws to lead to legal justice. In research on the perpendicular harmony that is studied is the law regarding a particular field, the order is based on each of these regulations' function so that the level of continuity between one rule and another will be visible. That the government in making rules does not overlap between one regulation and another, it is vital to harmonize existing laws and regulations. Regulations that already regulate rehabilitation services for addicts and victims of narcotics abuse.

The author raises it in writing entitled: "Harmonization of Legislation regarding Rehabilitation Service Standards for Addicts and Narcotics Abuse Victims". Based on the explanation above, the problem formulation in this study focuses on how the laws and regulations regarding the service standards for the Rehabilitation of addicts and victims of narcotics abuse and how are the harmonization of laws and regulations regarding the standard of rehabilitation services for addicts and victims of narcotics abuse. The scope of this writing is the statutory regulations governing the implementation of rehabilitation services for addicts and victims of narcotics abuse.

\section{B. Discussion}

\section{Regulations concerning Service Standards for the Rehabilitation of Addicts and} Victims of Narcotics Abuse

Victims of drug abuse do not choose their victims, making it a threat to the nation's survival. The impact of drug abuse can cause Indonesia to lose generations, which must be monitored and treated seriously. ${ }^{17}$ The Government of the Republic of Indonesia has initiated efforts to tackle the abuse of narcotics by ratifying the 1961 Single Convention on Narcotics in Geneva with Law Number 8 of 1976 concerning Narcotics and has signed the United Nations Convention on the trafficking of narcotics, 1988 in Vienna Austria on 27 March 1989. The rampant circulation of narcotics that has spread to all levels of society, including the younger generation, will significantly affect the nation's life and state in the future. But Indonesia itself is the circulation of narcotics, the distribution of narcotics is misused, the use of narcotics is not for treatment or research to endanger the nation and state. Practical crime prevention efforts should focus on various things related to the causes of crime and what methods are effectively used in tackling crime.

Rehabilitation measures are countermeasures that are repressive in nature, namely handling carried out after a criminal act, in this case, narcotics, in the form of supervision. The neurotic rehabilitation program is a series of coordinated and integrated efforts, consisting of medical efforts, mental, psychosocial, religious, educational, and vocational training to improve self-adjustment, independence, and self-help as well as achieving the ability to function according to their potential, both physical, mental, social and economic. Consequently, narcotics users are narcotics addicts who undergo treatment and/or treatment for drug addicts as stipulated by laws and government regulations. The expert determines the determination to undergo a period of treatment and treatment.

Based on the description above, the hierarchy or order of the laws and regulations regarding the handling of addicts and victims of narcotics abuse has met the provisions of Law Number 12 of 2011 concerning the formation of statutory regulations. ${ }^{18}$ With several institutions designated to implement rehabilitation programs, the number of addicts and

\footnotetext{
${ }^{17}$ Wira Yudha Alam et al., "Drug Eradication in Indonesian Millennials through School Visits," Journal of Drug and Alcohol Research 9 (2020), https://doi.org/10.4303/jdar/236089.

18 Tri Jata Ayu Pramesti, "Hierarki Peraturan Perundang-Undangan Di Indonesia," Hukum Online, 2020, https://www.hukumonline.com/klinik/detail/ulasan/c14012/hierarki-peraturan-perundang-undangan-diindonesia/.
} 
victims of narcotics abuse should be getting more and more services. ${ }^{19}$ But the opposite happened. The achievement is still meagre when compared to the number of narcotics abusers. The arrangement and implementation of the rehabilitation program are separated, this is because each Stakeholder has a standard in the implementation of the rehabilitation program. ${ }^{20}$ Efforts are needed to synergize the institutions that carry out sustainable rehabilitation programs. Implementing a national standard of rehabilitation services under the coordination of one institution is designated as the leading implementing sector.

\section{Harmonization of Regulations Governing the Rehabilitation of Addicts and Victims of Narcotics Abuse}

The process of proving the crime of gambling through the internet in court requires a technical approach because the evidence found can be in the form of electronic evidence that is still not recognized by the Procedural Law Code or Kitab Undang-Undang Hukum Acara Pidana (KUHAP). ${ }^{21}$ Therefore, it still has to be supported by expert testimony to be accepted in court. Investigators of the Subunit VC Satreskrim Polresta Bandar Lampung encountered obstacles in conducting investigations and investigations of online gambling crimes, which consisted of internal and external constraints. It is also necessary to know what are the weaknesses of the ITE Law are proving acts. ${ }^{22}$ It is also necessary to know the weaknesses of the ITE Law is proving online gambling crimes. The discussion can be described below.

Harmonization of laws and regulations that regulate rehabilitation services for addicts and victims of narcotics abuse is urgently needed. Addicts and victims of narcotics abuse who are sentenced to prison will not solve the problem. However, they will worsen their physical and mental conditions, because addicts and victims are placed in Corrections the same as narcotics dealers, will not be cured, and risk becoming a dealer. This situation then led to the formation of a Joint Regulation on the Handling of Narcotics Addicts and Victims of Narcotics Abuse into Rehabilitation Institutions and other regulations regarding Narcotics.

Analysis of the harmonization regulations is executed in 2 (two) ways: vertically and horizontally.

\section{a. Vertical Harmonization}

Vertical harmonization is when a piece of legislation is viewed from the strata's point of view or hierarchy of existing legislation. Vertical harmonization can be solved with the legal principle of lex superior derogate legi Inferiori (higher regulations/laws override lower regulations/laws). Vertical harmonization aims to see whether laws and regulations that apply to specific fields do not conflict with one another. Therefore, in this case, the author harmonizes Law Number 35 of 2009, Government Regulation Number 25 of 2011, Ministry of Health Regulation Number 50 of 2015, Ministry of Social Affairs Regulation Number 9 of 2017, and Head of BNN Regulation Number 24 of 2017. Synchronized provisions are listed in the table below.

\footnotetext{
${ }^{19}$ Risnawati Valentina et al., "Analisis Kualitas Pelayanan Rehabilitasi Sesuai Standar Pelayanan Bagi Penyalah Guna Napza Di Rumah Damai, Gunungpati, Semarang," Jurnal Kesehatan Masyarakat (Undip) 3, no. 3 (December 13, 2015): 2356-3346, http://ejournal-s1.undip.ac.id/index.php/jkm.

${ }^{20}$ Silvia Fitri and Rahmadani Yusran, "Implementasi Kebijakan Rehabilitasi Pengguna Narkoba Pada Badan Narkotika Nasional Provinsi Sumatera Barat," Journal of Civic Education 3, no. 3 (August 27, 2020): 231-42, https://doi.org/10.24036/jce.v3i3.400.

21 Eliasta Ketaren, "Cybercrime, Cyber Space, Dan Cyber Law," Jurnal TIMES, vol. 5, 2016, https://ejournal.stmik-time.ac.id/index.php/jurnalTIMES/article/view/556.

${ }^{22}$ Edmon Makarim, Kompilasi Hukum Telematika (Jakarta: Raja Grafindo, 2004).
} 
Table. 1. Definition of Medical Rehabilitation of Service Providers and Service Recipients.

\begin{tabular}{|c|c|c|c|c|}
\hline No & Regulations & $\begin{array}{c}\text { Definition of } \\
\text { Medical } \\
\text { Rehabilitation } \\
\end{array}$ & $\begin{array}{l}\text { Medical Rehabilitation } \\
\text { Administrators }\end{array}$ & $\begin{array}{l}\text { Recipients of Medical } \\
\text { Rehabilitation Services }\end{array}$ \\
\hline 1. & $\begin{array}{l}\text { Law No. } 35 \\
\text { of } 2009\end{array}$ & $\begin{array}{l}\text { A process of } \\
\text { integrated } \\
\text { treatment activities } \\
\text { to free addicts from } \\
\text { addiction to } \\
\text { Narcotics. }\end{array}$ & $\begin{array}{l}\text { Hospitals and Institutions. } \\
\text { Government-owned } \\
\text { agencies or the community } \\
\text { conducts individual } \\
\text { Rehabilitation. }\end{array}$ & $\begin{array}{l}\text { Addicts, victims of } \\
\text { narcotics abuse who } \\
\text { come voluntarily, and } \\
\text { addicts who are victims } \\
\text { of abuse. }\end{array}$ \\
\hline 2. & $\begin{array}{l}\text { Government } \\
\text { Regulations } \\
\text { No. } 25 \text { of } \\
2011\end{array}$ & $\begin{array}{l}\text { One process of } \\
\text { integrated therapy } \\
\text { activities to free } \\
\text { addicts from the } \\
\text { influence of } \\
\text { Narcotics }\end{array}$ & $\begin{array}{l}\text { Reporting Recipient } \\
\text { Institutions or Intitusi } \\
\text { Penerima Wajib Lapor } \\
\text { (IPWL) consist of Clinic or } \\
\text { Pusat Kesehatan } \\
\text { Masyarakat, Hospitals, } \\
\text { and/or medical } \\
\text { rehabilitation agencies } \\
\text { designated by the } \\
\text { government }\end{array}$ & $\begin{array}{l}\text { Addicts, victims of } \\
\text { abuse who report } \\
\text { themselves voluntarily } \\
\text { and who are undergoing } \\
\text { legal proceedings with } \\
\text { provisions. }\end{array}$ \\
\hline 3. & $\begin{array}{l}\text { Ministry of } \\
\text { Health } \\
\text { Regulation } \\
\text { No. } 50 \text { of } \\
2015\end{array}$ & $\begin{array}{l}\text { Does not explain } \\
\text { the definition but } \\
\text { explains the } \\
\text { technical } \\
\text { implementation of } \\
\text { medical } \\
\text { Rehabilitation }\end{array}$ & $\begin{array}{l}\text { Public Health Centres, } \\
\text { Puskesmas, government- } \\
\text { owned, local government, } \\
\text { or community-owned } \\
\text { medical rehabilitation } \\
\text { institutions that have been } \\
\text { designated as IPWL }\end{array}$ & $\begin{array}{l}\text { Users who come } \\
\text { voluntarily or at the } \\
\text { initiative of parents and } \\
\text { who are determined by } \\
\text { law }\end{array}$ \\
\hline 4. & $\begin{array}{l}\text { Head of BNN } \\
\text { Regulation } \\
\text { No. } 24 \text { of } \\
2017\end{array}$ & $\begin{array}{l}\text { Medical } \\
\text { Rehabilitation is an } \\
\text { integrated recovery } \\
\text { activity procedure } \\
\text { to free addicts from } \\
\text { narcotics. }\end{array}$ & $\begin{array}{l}\text { Rehabilitation institutions } \\
\text { that are within the BNN } \\
\text { environment and } \\
\text { collaborating institutions } \\
\text { with the BNN, the status of } \\
\text { the Rehabilitation } \\
\text { consisting Ministry of } \\
\text { Administrative and } \\
\text { Bureaucratic Reform of the } \\
\text { Republic of Indonesia for } \\
\text { BNN-owned institutions }\end{array}$ & $\begin{array}{l}\text { Medical Rehabilitation } \\
\text { and social Rehabilitation } \\
\text { through voluntary efforts } \\
\text { or at parents' initiative } \\
\text { (Voluntary) and as } \\
\text { determined by law } \\
\text { (Compulsory). }\end{array}$ \\
\hline
\end{tabular}

Source: BNN RI and UNODC, 2018 Collection of Laws and Regulations on the Handling of Addicts and Drug Abuse victims.

Based on the table above, data is obtained between Law Number 35 of 2009, Government Regulation Number 25 of 2011, and Regulation of the Minister of Health Number 50 of 2015 and Regulation of the Head of the National Narcotics Agency Number 24 of 2017, there is a discrepancy regarding the institutions that provide rehabilitation services are clinics, health centres, and hospitals. Owned by the government or society that meets the requirements as the Institution of Obligated Report Recipient or Institusi Penerima Wajib Lapor (IPWL) by the Ministry of Health. Rehabilitation institutions within the BNN must go through a stipulation from the Ministry of Administrative and Bureaucratic Reform of the Republic of Indonesia or Kementerian Pendayagunaan Aparatur Negara dan Reformasi Birokrasi Republik Indonesia (KEMENPAN RB), and recipients of medical rehabilitation services are voluntary, parental initiative, and law-related, there is no clear boundary between voluntary and legal 
compulsory. This has the potential to create uncertainty in the handling of addicts and victims of narcotics abuse.

Table. 2. Comparison of Provisions concerning the Definition, Service Providers, and Recipients of Social Rehabilitation Services.

\begin{tabular}{|c|c|c|c|c|}
\hline No & Regulations & $\begin{array}{l}\text { Definition of Social } \\
\text { Rehabilitation }\end{array}$ & $\begin{array}{l}\text { Social Rehabilitation } \\
\text { Service Providers }\end{array}$ & $\begin{array}{c}\text { Recipients of Social } \\
\text { Rehabilitation Services }\end{array}$ \\
\hline 1. & $\begin{array}{l}\text { Law No. } 35 \\
\text { of } 2009\end{array}$ & $\begin{array}{l}\text { An integrated } \\
\text { recovery process, } \\
\text { both physically, } \\
\text { mentally, and } \\
\text { socially, so that } \\
\text { former addicts can } \\
\text { again carry out } \\
\text { social functions in } \\
\text { people's lives. }\end{array}$ & $\begin{array}{l}\text { Both government } \\
\text { agencies and the } \\
\text { community carry out } \\
\text { social Rehabilitation of } \\
\text { former narcotics } \\
\text { addicts. }\end{array}$ & $\begin{array}{l}\text { Former addicts, victims of } \\
\text { narcotics abuse who come } \\
\text { to report themselves } \\
\text { voluntarily, and those who } \\
\text { are currently undergoing } \\
\text { legal proceedings with the } \\
\text { condition that they meet } \\
\text { Rehabilitation } \\
\text { requirements. }\end{array}$ \\
\hline 2. & $\begin{array}{l}\text { Government } \\
\text { Regulation } \\
\text { No. } 25 \text { of } \\
2011\end{array}$ & $\begin{array}{l}\text { The process of } \\
\text { returning functions } \\
\text { in an integrated } \\
\text { manner so that } \\
\text { former narcotics } \\
\text { addicts can return to } \\
\text { carry out social } \\
\text { functions in social } \\
\text { life }\end{array}$ & $\begin{array}{l}\text { The Social } \\
\text { Rehabilitation } \\
\text { Institution as an } \\
\text { Institution for } \\
\text { Reporting Obligations } \\
\text { Recipient (IPWL) is } \\
\text { established by the } \\
\text { minister in charge of } \\
\text { government affairs in } \\
\text { the social sector }\end{array}$ & $\begin{array}{l}\text { Former addicts, victims of } \\
\text { narcotics abuse who come } \\
\text { to report themselves } \\
\text { voluntarily, and who are } \\
\text { currently undergoing legal } \\
\text { proceedings provided they } \\
\text { meet the requirements to be } \\
\text { rehabilitated }\end{array}$ \\
\hline 3. & $\begin{array}{l}\text { Ministry of } \\
\text { Social } \\
\text { Affairs } \\
\text { Regulation } \\
\text { No. } 9 \text { of } 2010\end{array}$ & $\begin{array}{l}\text { The process of } \\
\text { functionalization } \\
\text { and development } \\
\text { enables a person to } \\
\text { be able to carry out } \\
\text { his social function in } \\
\text { social life }\end{array}$ & $\begin{array}{l}\text { Implementation of } \\
\text { social Rehabilitation is } \\
\text { carried out in IPWL, } \\
\text { namely Community } \\
\text { Health Centres } \\
\text { (Puskesmas), Hospitals, } \\
\text { and /or Medical and } \\
\text { social rehabilitation } \\
\text { institutions appointed } \\
\text { by the government }\end{array}$ & $\begin{array}{l}\text { Social Rehabilitation } \\
\text { through voluntary efforts at } \\
\text { the initiative of parents and } \\
\text { social Rehabilitation } \\
\text { determined by law }\end{array}$ \\
\hline 4. & $\begin{array}{l}\text { Head of BNN } \\
\text { Regulation } \\
\text { No } 24 \text { of } \\
2017\end{array}$ & $\begin{array}{l}\text { An integrated } \\
\text { recovery process, } \\
\text { both physically, } \\
\text { mentally, and } \\
\text { socially, so that } \\
\text { former narcotics } \\
\text { addicts can return to } \\
\text { social functions in } \\
\text { community life. }\end{array}$ & $\begin{array}{l}\text { Rehabilitation } \\
\text { Institutions within the } \\
\text { BNN and agencies are } \\
\text { collaborating with } \\
\text { BNN. The institution } \\
\text { includes the } \\
\text { institutional decree } \\
\text { Ministry of } \\
\text { Administrative and } \\
\text { Bureaucratic Reform of } \\
\text { the Republic of } \\
\text { Indonesia for the } \\
\text { Rehabilitation of the } \\
\text { BNN. }\end{array}$ & $\begin{array}{l}\text { Medical Rehabilitation and } \\
\text { social Rehabilitation } \\
\text { through voluntary efforts or } \\
\text { at parents' initiative } \\
\text { (voluntary) and medical } \\
\text { and social Rehabilitation as } \\
\text { prescribed by law } \\
\text { (compulsory). }\end{array}$ \\
\hline
\end{tabular}

Source: BNN RI and UNODC, 2018, Collection of Legislation regarding the handling of addicts and victims of Narcotics abuse 
Based on the description above, there is a mismatch regarding the Definition of Social Rehabilitation between Law Number 35 of 2009 concerning Narcotics and the Minister of Social Affairs Regulation, which still targets services for addicts, while the goal of social Rehabilitation itself is to prepare former addicts to return to society. According to the author, the Regulation of the Ministry of Social Affairs regulates that the implementation of social Rehabilitation can be done at the Community Health Centres or Puskesmas, is something difficult to realize because the Puskesmas is the Technical Implementation Unit of the Health Office / Ministry of Health. ${ }^{23}$ At present, there is no single standard that applies to all social rehabilitation institutions, resulting in overlapping appointments for social rehabilitation institutions. $^{24}$

\section{b. Horizontal Harmonization}

Horizontal harmonization is the harmonization of rules that examines the extent to which a written positive law rule is synchronized or compatible with other regulations, which have an equal position and regulate the same field. In this case, the researcher wants to synchronize the laws and regulations regarding the Ministry of Health Regulation Number 50 of 2015, the Ministry of Social Affairs Regulation Number 9 of 2017, and the Head of BNN Regulation Number 24 2017. The provisions that will be synchronized horizontally include, among others: $^{25}$

Table. 3. Determination of Service Provider Institutions

\begin{tabular}{|c|c|c|}
\hline No. & Regulations & Determination of Service Provider Institutions \\
\hline 1. & $\begin{array}{l}\text { Ministry of Health } \\
\text { Regulation No } 50 \text { of } \\
2015\end{array}$ & $\begin{array}{l}\text { The process of establishing a medical rehabilitation institution as an } \\
\text { IPWL that organizes a mandatory medical reporting and } \\
\text { rehabilitation process for addicts, abusers, and victims of narcotics } \\
\text { abuse begins with a proposal by the health service facility owner to } \\
\text { the Minister of Health. } \\
\text { To be assigned to the IPWL by the Minister of Health, a medical } \\
\text { rehabilitation medical facility must meet one of the following two } \\
\text { conditions: } \\
\text { 1. Has previously provided rehabilitation therapy services for } \\
\text { Psychotropic Narcotics and Addictive Substances or Narkotika, } \\
\text { Psikotropika, dan Zat Adiktif (NAPZA); } \\
\text { 2. Have Health Workers, which at least consist of doctors and nurses } \\
\text { who have received training in the field of NAPZA use disorders } \\
\text { registered at the Ministry of Health }\end{array}$ \\
\hline 2. & $\begin{array}{l}\text { Ministry of Social } \\
\text { Affairs Regulation } \\
\text { No. } 9 \text { of } 2017\end{array}$ & $\begin{array}{l}\text { The government and the community establish social rehabilitation } \\
\text { institutions for addicts and victims of narcotics abuse. The } \\
\text { establishment is following the provisions of laws and regulations in } \\
\text { the form of a legal entity. It must be registered with the Ministry of } \\
\text { Social Affairs or Social Institutions by their jurisdiction. }\end{array}$ \\
\hline 3. & Head of BNN & Implementation of Rehabilitation Service Standards is carried out by \\
\hline
\end{tabular}

${ }^{23}$ Lysa Angrayni and Yusliati, "Efektivitas Rehabilitasi Pecandu Narkotika (Studi Di Loka Rehabilitasi Badan Narkotika Nasional Batam)," Jurnal Hukum Respublica 18, no. 1 (2018): 78-96, https://doi.org/10.31849/RESPUBLICA.V18I1.3954.

${ }^{24}$ Sur yani. Fatwa Nurul Hakim, "Evaluasi Pelayanan Rehabilitasi Sosial Bagi Korban Penyalahguna Napza Di Prs Maunatul Mubarok," Media Informasi Penelitian Kesejahteraan Sosial 43, no. 1 (July 20, 2019): 79-88, https://doi.org/10.31105/MIPKS.V43I1.2203.

25 Andri Winjaya Laksana, "Tinjauan Hukum Pemidanaan Terhadap Pelaku Penyalahguna Narkotika Dengan Sistem Rehabilitasi," Jurnal Pembaharuan Hukum 2, no. 1 (July 8, 2016): 74, https://doi.org/10.26532/jph.v2i1.1417. 


\begin{tabular}{|l|l|l|}
\hline 2017 & $\begin{array}{l}\text { Regulation No. 24 of } \\
\text { institutions collaborating with BNN. }\end{array}$ \\
$\begin{array}{l}\text { Institutional status includes institutional decisions from the minister } \\
\text { in charge of State Apparatus Empowerment and Bureaucratic Reform } \\
\text { for BNN-owned institutions, institutional decisions from the ministry } \\
\text { in charge of health and social affairs for rehabilitation agencies } \\
\text { owned by the Government, Local Government, and Private } \\
\text { Communities. BNN can collaborate with other parties at home and } \\
\text { abroad in the Rehabilitation service midwife following laws and } \\
\text { regulations. }\end{array}$ \\
\hline
\end{tabular}

Source: BNN and UNODC, 2018. A collection of laws and regulations on the handling of addicts and victims of narcotics abuse

Based on the description above, there is an inequality between the Ministry of Health Regulation Number 50 of 2015, with the Ministry of Social Affairs Number 9 of 2017, and the Head of National Narcotics Agency (BNN) Regulation Number 24 of 2017 concerning the Establishment of a Rehabilitation Service Institution. According to the Ministry of Health's Regulation, medical rehabilitation service providers are appointed by the Health Minister. According to the Ministry of Social Affairs Regulation, social rehabilitation institutions are approved by the government. ${ }^{26}$ Meanwhile, according to the Regulation of the Head of the National Narcotics Agency, the establishment of rehabilitation institutions includes the decision of the institution from the Ministry of Administrative and Bureaucratic Reform of the Republic of Indonesia (KEMENPAN RB) to provide rehabilitation services belonging to the National Narcotics Agency, and the appointment of service implementers from state institutions in charge of health and social issues, for facilities administered by the Central Government, Regency/City Government, or privately owned facilities.

Comparison of Rehabilitation Service Implementation Standards between the Ministry of Health Regulation Number 50 of 2015, Ministry of Social Affairs Regulation Number 9 of 2017, and the Head of BNN Regulation Number 24 of 2017.

\section{Table. 4. Rehabilitation Service Implementation Standards}

\begin{tabular}{|c|c|c|}
\hline No. & Regulations & Rehabilitation Service Implementation Standards \\
\hline 1. & $\begin{array}{l}\text { Ministry of Health } \\
\text { Regulation No } 50 \text { of } 2015\end{array}$ & $\begin{array}{l}\text { 1. Service Program } \\
\text { Service procedures for addicts, abusers, and victims of } \\
\text { narcotics abuse who are voluntarily and undergoing medical } \\
\text { Rehabilitation carry out service procedures that include: } \\
\text { a. Assessment using the assessment form compulsory report } \\
\text { and medical Rehabilitation. } \\
\text { b. Urine test (urinalysis) to detect the presence or absence of } \\
\text { narcotics in the body. } \\
\text { c. Providing necessary drug/NAPZA addiction counselling } \\
\text { to assess the patient's understanding of the disease and } \\
\text { understand recovery. } \\
\text { d. HIV counselling is carried out for needle users. } \\
\text { e. Other supporting examinations if necessary. } \\
\text { f. Formulation of a therapy plan, including a medical } \\
\text { rehabilitation plan and/or social Rehabilitation. }\end{array}$ \\
\hline
\end{tabular}

${ }^{26}$ Gusti Ayu et al., "Perlindungan Hukum Terhadap Korban Tindak Pidana Penyalahgunaan Narkotika Di Kabupaten Buleleng," Tahun, vol. 2, 20, https://ejournal.undiksha.ac.id/index.php/jatayu/article/view/23924. 


\begin{tabular}{|c|c|c|}
\hline & & $\begin{array}{l}\text { g. Medical Rehabilitation according to the therapy plan can } \\
\text { be outpatient or inpatient. } \\
\text { 2. Human Resources } \\
\text { Human Resources covers health workers consisting of at least } \\
\text { doctors and nurses who have received training in } \\
\text { drug/NAPZA use disorders registered at the Ministry of } \\
\text { Health. } \\
\text { 3. Facilities and Infrastructure } \\
\text { Medical rehabilitation facilities for addicts, abusers, and } \\
\text { victims of narcotics abuse must meet the following criteria: } \\
\text { outpatient: } \\
\text { a. Has social examination and intervention rooms. } \\
\text { b. Has an outpatient program in the form of symptomatic } \\
\text { services. And simple sausage interventions. } \\
\text { c. Has standard operational procedures for outpatient } \\
\text { drug/NAPZA rehabilitation services. } \\
\text { inpatient: } \\
\text { a. Have a bed for treatment duration as short as three } \\
\text { months. } \\
\text { b. Has an inpatient drug/NAPZA rehabilitation program. } \\
\text { c. Has a standard operating procedure for inpatient } \\
\text { drug/NAPZA rehabilitation services. } \\
\text { d. Has minimal security procedures, consisting of: } \\
\text { - Recording visitors in and out. } \\
\text { - Physical and luggage examination every time you enter } \\
\text { the program to not bring various drugs/NAPZA and } \\
\text { sharp objects into the rehabilitation facility. } \\
\text { - Security Guard Officer. } \\
\text { - Safe facilities and infrastructure so that patients avoid } \\
\text { the possibility of injuring themselves, injuring others, } \\
\text { and running away. }\end{array}$ \\
\hline 2 & $\begin{array}{l}\text { Ministry of Social Affairs } \\
\text { Regulation No. } 9 \text { of } 2017\end{array}$ & $\begin{array}{l}\text { 1. Social Service } \\
\text { Rehabilitation service programs for addicts and drug/NAPZA } \\
\text { abuse victims are carried out in the form of Motivation and } \\
\text { psychological diagnosis, care and nurturing, vocational } \\
\text { training and entrepreneurship development, mental, spiritual } \\
\text { guidance, physical guidance, social guidance and } \\
\text { psychosocial counselling, accessibility services, social } \\
\text { assistance, and assistance. } \\
\text { 2. Human Resources } \\
\text { Human resources in the field of social Rehabilitation for } \\
\text { addicts and victims of drug abuse consist of: } \\
\text { a. The prominent officers consist of Social Workers, Social } \\
\text { Welfare Workers/Social Volunteers, Addiction } \\
\text { Counsellors, and Nurses. } \\
\text { b. Additional staff includes Psychiatrists, Psychologists, } \\
\text { Doctors, Skills Instructors, Social Instructors. } \\
\text { 3. Facilities and Infrastructure } \\
\text { Facilities and infrastructure for social rehabilitation } \\
\text { institutions for addicts and victims of drug abuse include } \\
\text { physical facilities and infrastructure and technical instruments } \\
\text { for social Rehabilitation consisting of: } \\
\text { a. Offices consist of the leadership room, staff workroom, } \\
\text { meeting room, living room, documentation room, data and }\end{array}$ \\
\hline
\end{tabular}




\begin{tabular}{|c|c|c|}
\hline & & $\begin{array}{l}\text { information room, library room, bathroom, and kitchen. } \\
\text { b. Technical service room consisting of dormitory room, } \\
\text { caregiver room, diagnosis room, psychosocial counselling } \\
\text { room, observation room, a production installation room, } \\
\text { sports and physical guidance room, mental and social } \\
\text { guidance room, skills practice room, and art room. } \\
\text { c. The public service room consists of a dining room, study } \\
\text { room, prayer room, health room, hall, security post, living } \\
\text { room, warehouse, bathroom, parking area, and the board's } \\
\text { official residence. } \\
\text { d. Equipment for social rehabilitation institutions for addicts } \\
\text { and drug/NAPZA abuse victims, consisting of office } \\
\text { support equipment, communication equipment, lighting, } \\
\text { water and clean water installations, assistive equipment } \\
\text { for service recipients, and technical service support } \\
\text { equipment. } \\
\text { e. Transportation consists of office transportation means and } \\
\text { service recipient transportation. } \\
\text { f. Food and clothing for service recipients. }\end{array}$ \\
\hline 3. & $\begin{array}{l}\text { Head of BNN Regulation } \\
\text { No. } 24 \text { of } 2017\end{array}$ & $\begin{array}{l}\text { 1. Social Service } \\
\text { Standard operation and service flow include: } \\
\text { a. Initial admission is carried out by rehabilitation service } \\
\text { officers who have been trained in carrying out } \\
\text { comprehensive assessments, including Observation, } \\
\text { Assessment using intensive instruments, and medical } \\
\text { examinations as needed. } \\
\text { b. Rehabilitation that is carried out based on client needs } \\
\text { obtained from the initial admission process includes: } \\
\text { - Medical Rehabilitation. Includes minimal services, } \\
\text { including detoxification therapy, symptomatic therapy, } \\
\text { and psychosocial interventions through counseling, } \\
\text { motivational interviews, behavioral therapy, and } \\
\text { cognitive, including relapse prevention. } \\
\text { - Social Rehabilitation. Implemented in the form of } \\
\text { psychosocial assessment and diagnosis, psychosocial } \\
\text { Motivation and intervention, care and care for child } \\
\text { clients, vocational training and entrepreneurship } \\
\text { development, mental and spiritual guidance, physical } \\
\text { guidance, re-socialization guidance, periodic evaluation, } \\
\text { and/or referral. } \\
\text { Post-Rehabilitation. Implemented after undergoing } \\
\text { medical Rehabilitation and/or social Rehabilitation } \\
\text { required by a resume of treatment or a certificate of } \\
\text { completion of Rehabilitation. Post-rehabilitation activities } \\
\text { include Prevention of recurrence, Self-development } \\
\text { including the ability to solve problems, resolve school } \\
\text { dropouts, and vocational skills, case management, self- } \\
\text { help group meetings, family support groups, crisis } \\
\text { management, mentoring, and monitoring, both through } \\
\text { various means of communication media, as well as face- } \\
\text { to-face and periodic visitations and development } \\
\text { evaluations. } \\
\text { Euman Resources } \\
\text { Executors of medical rehabilitation services are doctors and }\end{array}$ \\
\hline
\end{tabular}




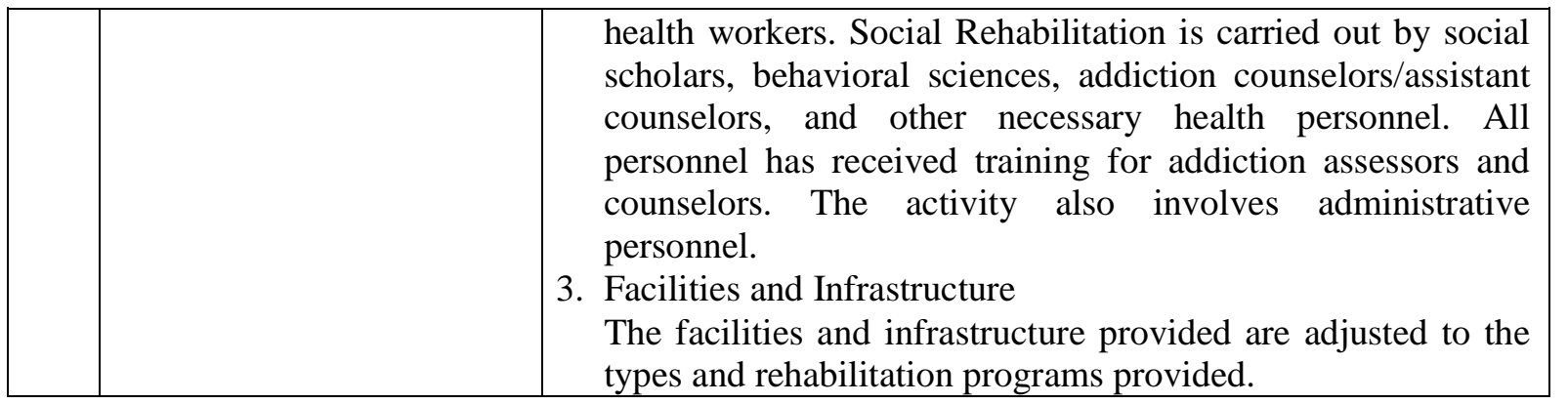

Source: BNN RI and UNODC, 2018. Collection of Legislation concerning Handling of Addicts and Victims of Narcotics Abuse.

The provisions in Law Number 35 of 2009 concerning Narcotics, Implementation of Medical Rehabilitation are the responsibility of the Ministry of Health. The implementation of Social Rehabilitation is the responsibility of the Ministry of Social Affairs, and NonMinisterial Government Agencies. The National Narcotics Agency is responsible for strengthening institutions that provide medical rehabilitation services and social service rehabilitation. Based on the description above, it is concluded that between the Ministry of Health Regulation Number 50 of 2015, with the Ministry of Social Affairs Number 9 of 2017, and Head of BNN Regulation Number 24 of 2017, there are similarities regarding service programs, human resources, and infrastructure, this causes overlapping and tug-of-war of implementation. Rehabilitation services. ${ }^{27}$

According to the Ministry of Health Regulation, there is a social rehabilitation program in the implementation of the medical rehabilitation service program, and there is a medical rehabilitation program in the Ministry of Social Affairs Regulation. ${ }^{28}$ The author argues that the Medical Rehabilitation Program and social Rehabilitation are two different things but cannot be separated and need to meet that in rehabilitating addicts and victims of abuse. The task of providing strengthening rehabilitation institutions is to increase the capacity of human resources and budget support for the rehabilitation program. Set up a rehabilitation institution that provides rehabilitation services and has a complete rehabilitation program through the Post-rehabilitation program. ${ }^{29}$

Sources of funding for the implementation of Rehabilitation in rehabilitation service providers come from the state budget or Anggaran Pendapatan dan Belanja Negara (APBN) and other sources, as described in the table below:

Table. 5. Funding Sources for the Implementation of Rehabilitation Services

\begin{tabular}{|c|l|l|}
\hline No. & \multicolumn{1}{|c|}{ Regulation } & \multicolumn{1}{|c|}{ Sources of funding } \\
\hline 1. & $\begin{array}{l}\text { Ministry of Health } \\
\text { Regulation No 50 of 2015 }\end{array}$ & $\begin{array}{l}\text { State Budget/APBN under the provisions of statutory } \\
\text { regulations }\end{array}$ \\
\hline 2. & $\begin{array}{l}\text { Ministry of Social Affairs } \\
\text { Regulation No. } 9 \text { of } 2017\end{array}$ & $\begin{array}{l}\text { State budget/APBN, Community Contributions, and Legal } \\
\text { sources of funding under the legislation's provisions (allocated } \\
\text { by the government under the Laws and Regulations). }\end{array}$ \\
\hline
\end{tabular}

27 Seto Michiko, "Pelayanan Rehabilitasi Badan Narkotika Nasional Provinsi Jawa Timur Terhadap Penyalahguna Narkoba," DIA Jurnal Ilmiah Administrasi Publik 14, no. 01 (June 30, 2016), https://doi.org/10.30996/DIA.V14I01.1022.

${ }^{28}$ Insan Firdaus, "Analisa Kebijakan Optimalisasi Pelaksanaan Rehabilitasi Narkotika Di Unit Pelayanan Teknis Pemasyarakatan," Jurnal Ilmiah Kebijakan Hukum 14, no. 3 (November 2, 2020): 469, https://doi.org/10.30641/kebijakan.2020.v14.469-492.

${ }^{29}$ Farrin Rizki Fernanda, "Efektivitas Pelaksanaan Rehabilitasi Sosial Terhadap Warga Binaan Pemasyarakatan Di Lembaga Pemasyarakatan Narkotika Kelas IIA Lubuk Linggau," Syntax Literate ; Jurnal Ilmiah Indonesia 5, no. 9 (September 20, 2020): 824-32, https://doi.org/10.36418/SYNTAX-LITERATE.V5I9.940. 
\begin{tabular}{l|l|l}
3. & $\begin{array}{l}\text { Head of BNN Regulation } \\
\text { No. } 24 \text { of } 2017\end{array}$ & State budget/APBN under statutory provisions.
\end{tabular}

Source: BNN RI and UNODC, 2018. A collection of laws and regulations on the handling of addicts and victims of narcotics abuse.

Based on the description above, there are differences in funding sources for rehabilitation programs between one institution and another; this can cause maladministration of services such as varying rates.

\section{Conclusion}

From the results of this study, the authors conclude that the regulations for implementing rehabilitation services follow the hierarchy of Law Number 12 of 2011 concerning the formation of statutory regulations. The implementation of each rehabilitation program has a Service Standard. This causes the implementation of medical and social Rehabilitation to separate, so that service recipients' services are not comprehensive.

Harmonization Regulations for administering rehabilitation services for addicts and victims of narcotics abuse are vertically inconsistent with the definition of medical and social Rehabilitation, service providers, and service recipients. Horizontally, there are discrepancies regarding the implementation agency's determination, service standards, which include service programs, human resources, infrastructure, and activity funding sources. So, there is an overlap in regulation and implementation. A better cooperation pattern between related institutions is needed in administering the rehabilitation program for addicts and victims of narcotics abuse.

\section{Bibliography}

\section{A. Books}

Makarim, Edmon. Kompilasi Hukum Telematika. Jakarta: Raja Grafindo, 2004.

Muntaha. Hukum Pidana Malapraktik: Pertanggungjawaban Dan Penghapus Pidana. Jakarta Timur: Sinar Grafika, 2017.

Rifai, Eddy. Penegakan Hukum Tindak Pidana Korupsi. Bandar Lampung: Justice Publisher, 2014.

\section{B. Journals}

Alam, Wira Yudha, Kacung Marijan, Siti Aminah, and Teguh Dwi Putranto. "Drug Eradication in Indonesian Millennials through School Visits." Journal of Drug and Alcohol Research 9 (2020). https://doi.org/10.4303/jdar/236089.

Angrayni, Lysa, and Yusliati. "Efektivitas Rehabilitasi Pecandu Narkotika (Studi Di Loka Rehabilitasi Badan Narkotika Nasional Batam)." Jurnal Hukum Respublica 18, no. 1 (2018): 78-96. https://doi.org/10.31849/RESPUBLICA.V18I1.3954.

Ayu, Gusti, Novira Santi, Ni Putu, Rai Yuliartini, Dewa Gede, and Sudika Mangku. "Perlindungan Hukum Terhadap Korban Tindak Pidana Penyalahgunaan Narkotika Di Kabupaten Buleleng." Tahun. Vol. 2, February 28, 2019. https://ejournal.undiksha.ac.id/index.php/jatayu/article/view/23924.

Falah, Muhammad Fajrul. "Reformulasi Penetapan Sanksi Rehabilitasi Bagi Pecandu Narkotika." JURNAL LEGALITAS 12, no. 1 (February 3, 2019): 25-47. https://doi.org/10.33756/JELTA.V12I1.5380.

Fatwa Nurul Hakim, Sur yani. "Evaluasi Pelayanan Rehabilitasi Sosial Bagi Korban 
Penyalahguna Napza Di Prs Maunatul Mubarok." Media Informasi Penelitian Kesejahteraan Sosial 43, no. 1 (July 20, 2019): 79-88. https://doi.org/10.31105/MIPKS.V43I1.2203.

Fernanda, Farrin Rizki. "Efektivitas Pelaksanaan Rehabilitasi Sosial Terhadap Warga Binaan Pemasyarakatan Di Lembaga Pemasyarakatan Narkotika Kelas IIA Lubuk Linggau." Syntax Literate; Jurnal Ilmiah Indonesia 5, no. 9 (September 20, 2020): 824-32. https://doi.org/10.36418/SYNTAX-LITERATE.V5I9.940.

Firdaus, Insan. "Analisa Kebijakan Optimalisasi Pelaksanaan Rehabilitasi Narkotika Di Unit Pelayanan Teknis Pemasyarakatan." Jurnal Ilmiah Kebijakan Hukum 14, no. 3 (November 2, 2020): 469. https://doi.org/10.30641/kebijakan.2020.v14.469-492.

Fitri, Silvia, and Rahmadani Yusran. "Implementasi Kebijakan Rehabilitasi Pengguna Narkoba Pada Badan Narkotika Nasional Provinsi Sumatera Barat." Journal of Civic Education 3, no. 3 (August 27, 2020): 231-42. https://doi.org/10.24036/jce.v3i3.400.

Hariyanti, Anggelina. "Strategi Program Pencegahan Penyalahgunaan Narkoba Pada Badan Narkotika Nasional Provinsi Kalimantan Tengah." Pencerah Publik 6, no. 2 (October 7 , 2019): 9-15. https://doi.org/10.33084/pencerah.v6i2.1075.

Irfan Ardani, Sri Handayani. "Stigma Terhadap Orang Dengan HIV/AIDS (ODHA) Sebagai Hambatan Pencarian Pengobatan: Studi Kasus Pada Pecandu Narkoba Suntik Di Jakarta . Indonesian Bulletin of Health Research 45, no. 2 (2017): 81-88. https://doi.org/10.22435/bpk.v45i2.6042.81-88.

Iswahyuni, Ari. "Kedudukan Ancaman Pidana Minimal Dalam Undang- Undang Nomor 35 Tahun 2009 Tentang Narkotika Pasca Dikeluarkannya Surat Edaran Mahkamah Agung Nomor 3 Tahun 2015." Jurnal Panorama Hukum 3, no. 1 (July 5, 2018): 19-32. https://doi.org/10.21067/jph.v3i1.2321.

Ketaren, Eliasta. "Cybercrime, Cyber Space, Dan Cyber Law.” Jurnal TIMES. Vol. 5, 2016. https://ejournal.stmik-time.ac.id/index.php/jurnalTIMES/article/view/556.

Laksana, Andri Winjaya. "Tinjauan Hukum Pemidanaan Terhadap Pelaku Penyalahguna Narkotika Dengan Sistem Rehabilitasi." Jurnal Pembaharuan Hukum 2, no. 1 (July 8, 2016): 74. https://doi.org/10.26532/jph.v2i1.1417.

Michiko, Seto. "Pelayanan Rehabilitasi Badan Narkotika Nasional Provinsi Jawa Timur Terhadap Penyalahguna Narkoba." DIA Jurnal Ilmiah Administrasi Publik 14, no. 01 (June 30, 2016). https://doi.org/10.30996/DIA.V14I01.1022.

Sabarinah. "Use of Drug Treatment and Rehabilitation Services in Indonesia: Findings of the 2014 National Narcotic Survey." Asia-Pacific Journal of Public Health 31, no. 6 (2019): 548-58. https://doi.org/10.1177/1010539519872343.

Saefudin, Yusuf, Hartiwiningsih, and Isharyanto. "Rehabilitation Policy for Drugs Abuse in Indonesia." Indian Journal of Forensic Medicine \& Toxicology 14, no. 4 (2020): 411115.

Susiyanto, Randy Pradityo, and Rosyidin. "Rehabilitation Of Narcotic Abuse Victims: (Integrated Assessments from National Narcotics Board of Indonesian Republic ) Turkish Journal of Computer and Mathematics Education." Turkish Journal of Computer and Mathematics Education 12, no. 13 (2021): 4150-53.

Valentina, Risnawati, Anneke Suparwati, Asmita Wigati, Peminatan Administrasi, Kebijakan Kesehatan, and Kesehatan Masyarakat. "Analisis Kualitas Pelayanan Rehabilitasi Sesuai Standar Pelayanan Bagi Penyalah Guna Napza Di Rumah Damai, Gunungpati, Semarang." Jurnal Kesehatan Masyarakat (Undip) 3, no. 3 (December 13, 2015): 23563346. http://ejournal-s1.undip.ac.id/index.php/jkm.

Warjiyati, Sri, Daniel Susilo, and Suyanto. "Justice Collaboration on Social Media: Drugs and Narcotics Abuse Prevention Promotion." Journal of Drug and Alcohol Research 9 (2020): 1-6. https://doi.org/10.4303/jdar/236111. 


\section{Regulations}

Government Regulation of the Republic of Indonesia Number 25 of 2011 concerning The Mandatory Report for Narcotics Addicts.

Law Number 35 of 2009 concerning Narcotics

Law Number 36 of 2009 concerning Health

Local Regulation of Lampung Province Number 1 of 2019 concerning Facilitation for the Prevention of Abuse of Narcotics, Psychotropic, and other Addictive Substances.

Regulation of the Head of the National Narcotics Agency of the Republic of Indonesia Number 24 of 2017 concerning Rehabilitation Service Standards for Narcotics Addicts and Victims of Narcotics Abuse.

Regulation of the Ministry of Health Number 50 of 2015 concerning Technical Guidelines for the Implementation of Compulsory Medical Report and Rehabilitation for Addicts, Abusers, and Victims of Narcotics Abuse.

Regulation of the Ministry of Social Affairs Number 9 of 2017 concerning National Standards for the Social Rehabilitation of Victims of Narcotics Abuse, Tropical Psychology, and other Addictive Substances.

\section{Internet}

Hatta, Muhammad. "Mati Suri Rehabilitasi Adiksi." Tempo, 2019. https://kolom.tempo.co/read/1175460/mati-suri-rehabilitasi-adiksi/full\&view=ok.

Pramesti, Tri Jata Ayu. "Hierarki Peraturan Perundang-Undangan Di Indonesia." Hukum Online, 2020. https://www.hukumonline.com/klinik/detail/ulasan/cl4012/hierarkiperaturan-perundang-undangan-di-indonesia/.

Rachmawati, Ira. "Buwas: Pengguna Narkoba Di Indonesia Meningkat Hingga 5,9 Juta Orang."

https://regional.kompas.com/read/2016/01/11/14313191/Buwas.Pengguna.Narkoba.di.In donesia.Menin. 